
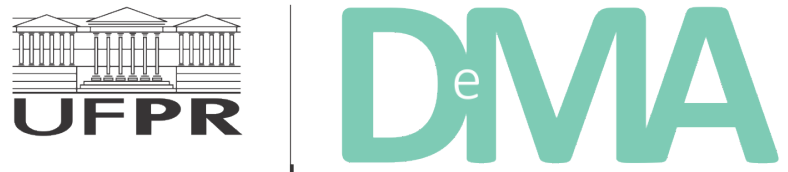

\title{
Women in the wake: expanding the legacy of Chico Mendes in Brazil's environmental movement
}

\section{Mulheres avançando: expandindo o legado de Chico Mendes no movimento ambiental do Brasil}

\author{
Patricia SHANLEY ${ }^{*}$, Fatima Cristina da SILVA ${ }^{2}$, Trilby MacDONALD ${ }^{1}$, Murilo da Serra SILVA ${ }^{3}$ \\ ${ }^{1}$ Woods \& Wayside International, Hopewell, NJ, USA. \\ ${ }^{2}$ Chico Mendes Extractive Reserve, Rio Branco, AC, Brasil. \\ ${ }^{3}$ Instituto Federal de Educação, Ciência e Tecnologia do Pará (IFPA) Campus Rural de Marabá, PA, Brasil. \\ *E-mail of contact: pshanley@woods-wayside.org
}

Article received in April 10, 2018, final version accepted in August 30, 2018.

ABSTRACT: Since the death of Chico Mendes three decades ago, nearly half of the Amazon forest area has been conserved through the collective sacrifice and struggle of thousands of forest-reliant families in Brazil, twined with political will and dense scientific and technical capacity. The key position that once marginalized, rural women have played in this struggle, however, is often obscured. This paper describes the role of women, some eminent and others lesser known, in the conservation movement inspired by Chico Mendes in Brazil. Thirty years ago, women were not permitted to be union members; today, $40 \%$ of the National Council of Extractivist Populations (CNS) leadership is female, and $25 \%$ of conservation units are led by women. Brazilian women occupy positions across the full spectrum of politics from grassroots to crucial positions in government, unions and civil society organizations. As women have gained power, they have also become targets. Of the 818 assassinations recorded by the Comissão Pastoral da Terra" (CPT) between 1997 and 2017, 7\% have been women. Their deaths have not been forgotten. During 2017's March of the Margaridas, in support of women's rights and in remembrance of those who have died for the cause, an estimated one hundred thousand women have participated. Since Mendes' death, the movement to conserve forests and secure land for smallholders in Brazil has not abated, but grown and evolved through crosssectoral collaborations, intergenerational exchange, strategic advocacy across vast geographic areas, and shared bonds born of struggle. The paper highlights the vital role of women in expanding and concretizing a globally significant forest conservation movement sparked by a man with a vision.

Keywords: extractive reserves; women; Amazonia; social movements. 
RESUMO: Desde a morte de Chico Mendes, há três décadas, quase a metade da área de floresta amazônica foi conservada, devido ao sacrifício coletivo e a luta de milhares de famílias dependentes da floresta no Brasil, entrelaçada com vontade política e densa capacidade científica e técnica. As mulheres têm desempenhado posição chave na luta para a manutenção dos ecossistemas naturais, apesar de em muitos casos não serem reconhecidas. Este artigo descreve o papel de mulheres, algumas eminentes e outras menos conhecidas, no movimento de conservação inspirado pelo Chico Mendes no Brasil. Trinta anos atrás, as mulheres não podiam ser sindicalizadas; hoje, $40 \%$ da liderança do Conselho Nacional de Populações Extrativistas (CNS) é feminina e $25 \%$ das unidades de conservação são lideradas por mulheres. As mulheres brasileiras ocupam posições em todo o campo da política, desde a base até posições cruciais no governo, sindicatos e organizações da sociedade civil. Como as mulheres ganharam poder, elas também se tornaram alvos. Dos 818 assassinatos por conflitos no campo, registrados pela Comissão Pastoral da Terra (CPT) entre 1997 e 2017, 7,3\% foram mulheres. Suas mortes não são esquecidas. Durante a Marcha das Margaridas de 2017, em apoio aos direitos das mulheres e em memória daqueles que morreram pela causa, cerca de cem mil mulheres participaram. Desde a morte de Chico Mendes, o movimento para conservar florestas e garantir terras para pequenos proprietários no Brasil não diminuiu, mas evoluiu por meio do intercâmbio intergeracional, da defesa estratégica em vastas áreas geográficas e de laços compartilhados nascidos da luta. O documento destaca o papel vital das mulheres na expansão e concretização de um movimento de conservação florestal, globalmente significativo, desencadeado por um homem de visão.

Palavras-chave: reservas extrativistas; mulheres; Amazônia; movimentos sociais.

\section{Introduction}

In his life and death, Chico Mendes was a startling catalyst of social mobilization for conserving forests, with notions of culture, place and territory as essential to the identity and cause of social movements. By 2003, just 15 years after Mendes' death, smallholders and economically disenfranchised groups, such as extractivists and rubber tappers, had successfully proposed and advocated for large scale designation of areas of conservation and sustainable use in the Brazilian Amazon (Schwartzman et al., 2010). This success entailed negotiations at the federal level, where pioneering legislation was enacted to conserve forested areas (Veríssimo, et al., 2011). Deforestation continues to threaten protected areas in the Brazilian Amazon, and factors including their location, scale, surrounding development pressures and level of enforcement are critical in determining the extent of their effectiveness (Pfaff et al., 2015). However, over the last decade, numerous factors including the establishment of a preeminent forest cover monitoring system, have resulted in a drastic reduction of deforestation, with $46 \%$ of the Brazilian Amazon now being in protected areas (Fonseca et al., 2017). While a conjuncture of many factors including political will, scientific and technical capacity, and social mobilization came together to reach Mendes' goals, the significant role that women have played in this struggle, and its success, are often obscured.

Chico Mendes was not particularly known for his work with women, but the movement he spearheaded paved the way for women to become powerful leaders in both the extractivist and the rural workers movements. He worked closely with several influential women activists, and towards the end of his life, made strategic efforts to reach 
out to women as a category, both to create political alliances with leaders like Marina Silva and to encourage the participation of women in the rural workers movement more broadly. Through these embryonic beginnings we glimpse what might have been next on the agenda for Chico Mendes, potentially embracing women's participation more fully. However, women did not wait to be summoned.

In the wake of his assassination, women stepped up the fight for environmental justice for rural Amazonians. Mendes had laid the groundwork by initiating the unification of rubber tappers and indigenous peoples in defense of Amazonia with the Alliance of Forest Peoples, linking the rights of forest dwellers to pursue their traditional lifeways with environmental rights (Memórias da Floresta, 2010). The alignment of the rural workers movement to secure land rights, and the rubber tappers and indigenous movements to secure forest rights, created a formidable force to counterbalance the influence of large landowners in politics and contain the advance of cattle ranches and agro-industries into the Amazon region (Delgado \& Lopes, 1992; Allegretti, 1998; Brown \& Rosendo, 2000; Schwartzman et al., 2010).

In the years that followed, women broadened the agenda to encompass women's rights, not only filling the space Chico Mendes created but becoming centrally involved in mapping out the strategy for moving ahead. This burgeoning of female activism was inevitable as there were already important female leaders who were part of the movement with him, some of whom worked with him directly, while others worked parallel to him in different regions (Shanley et al., 2011). The legacy of Chico Mendes is powerfully evident in the commitment of these women to defend the Amazon forests, streams, animals, and the way of life of extractivist populations from the relentless expansion of the cattle, soy and logging industries. These key female figures harnessed the impact of Chico Mendes' fame and the international outcry that followed his murder to influence the shape of forest policy and the rights of rural workers to land.

Women became union leaders driven to unite rural workers during a critical time of conflict, winning the legal right to occupy hundreds of thousands of hectares of forest and agricultural land. These grassroots efforts laid the groundwork for the future of the rural workers movement (Anderson, 1992) and many of these women went on to have long careers in the movement and are still active today. Like Chico Mendes, others, such as Maria do Espírito Santo, had their work towards achieving human rights and environmental justice cut short by assassins who wanted to stop their progress. But the movement, far from fading, continues to evolve. The social and environmental movement founded in the countryside coincided with international tendencies at the time, which catapulted it to international acclaim (Allegretti, 2008). Over the intervening years, new global movements have spawned in support of urban poor, disenfranchised, women, and minority populations.

The $30^{\text {th }}$ anniversary of Chico Mendes's death is a fitting time to tell the stories of some of the bold Amazonian women who helped make historic gains in conservation and workers' rights possible in Brazil. Some of these women became well recognized leaders, others remained anonymous to the public, but all were working towards the same goals that Chico Mendes fought and died to achieve: prosperity, health, and security for the people of the 
Amazon, and conservation of the abundant forests, rivers, and wildlife they depend upon to survive.

\section{Theoretical context}

The movement Chico Mendes helped to catalyze can be characterized in numerous theoretical contexts; two of relevance include resource mobilization theory (Jenkins, 1983), and collective identity as a mobilizing force (Polletta \& Jaspar, 2001). According to these theories, shared political opposition to dominant political and economic forces forges common goals and solidarity through informal networks. Researchers have also noted that effective comprehension of social movements is advanced by understanding the lived experiences of individual activists (Polletta \& Jaspar, 2001).

This personal perspective of an activist's life may be particularly important when assessing the role of women in social change, as history has been defined through the male perspective, immortalizing often charismatic men as transformative figures. Such alluring narratives fit into an historical pattern which obscures less prominent people who have been instrumental in working toward social and political transformations (Edwards, 2012). Bringing the critique of development to contemporary revolutionary movements in Latin America, Saldaña-Portillo (2003) further posits that these have been inherently masculine, anti-feminist and anti-indigenous, promoting transformation of ethnicity for the common good. In the case of Chico Mendes however, it can be argued that this was not so, as he encouraged women to assume positions of power and urged his followers to support women in their campaigns for political office. Marina Silva describes him as someone with "tactful style, democratic behavior, simple ways and indisputable leadership... Perhaps his greatest legacy and what we try to cultivate, is his special way of sounding out his comrades before making decisions, his tireless devotion to making alliances" (Rodrigues \& Rabben, 2007).

Alexander (2006) notes that a new generation of women-of-color activists are benefitting from the practice of transgenerational memory, a spiritual practice she characterizes as an antidote to oppression. She conjectures that alternative histories are needed to forge new futures. Women working in the thick of social movements, confronting complex issues of subjugation and violence, generally have neither the time nor the space to document and memorialize the strategic thinking, illuminating life histories and complex operations behind the movement. Although thousands of women have taken up the cause that Chico Mendes stood for, few have become household names. In reconfiguring the narrative of social and environmental justice in Amazonia, it is critical to recall the names and stories of at least some of the many women who not only joined the struggle that Chico Mendes is known for, but who nurtured and broadened it to include oppressed rural and urban women. These women are still fighting, and like Chico Mendes and the rubber tapping families he stood for, some, such as Sister Dorothy Stang, have also died for the cause.

\section{Roots of rebellion - the role of women in rubber tapping}

Rubber tapping began as an indigenous practice that was adopted by the mixed descendants of 
native people and Portuguese settlers who populate the region today. (Hecht, 2007). At the height of the rubber boom from 1879-1912, women were trafficked from Belém and Manaus as sex slaves, and women who tapped rubber were commonly slaves or employed by others (Araujo, 1987; Hemming, 1987; Simonian, 1995). As rubber prices fell, many Northeastern men left the forest in search of opportunities elsewhere. The approximately 80,000 men who stayed became part of local extractivist communities, harvesting latex as their main source of income along with subsistence hunting, fishing, and farming. In the 1970s, men like Chico Mendes started to organize and create cooperatives to increase efficiency, prices, and distribution of rubber. As ranchers began to encroach, these same men became activists to protect the forests they depended upon for their livelihoods.

Women, in general, were not politically active during these years. The rubber tappers union only allowed one member per family and in households headed by a married couple that member was always the man. The one instance when women's activism was encouraged was the empate, a showdown between rubber tapper communities and workers sent in to clear the forests for pasture and soy plantations. Women and children were recruited to stand on the front lines of the empates, knowing that the workers would be more likely to back down rather than risk injuring them (Mendes 1988; Campbell, 1997). Empates were risky but highly effective, gaining the movement fame and delaying the advance of ranchers into forests, while leaders like Chico Mendes maneuvered to enact policies that would protect the forests over the long term.

\section{Key women leaders born out of the rubber tappers movement in Acre}

Several women who participated in the empates went on to become important leaders. Maria Osmarina da Silva, known as Marina Silva, and her compatriot Julia Feitoza were among the young women from rubber tapping families who got their start in activism through the empates. One of 11 children, Marina began working to help support her family by extracting latex at age ten (Flor, 2010). When she was 16 years old, she moved to Acre's capital of Rio Branco to receive medical treatment and it was there that she learned to read and write. Feitoza also moved to Rio Branco from the interior with her mother at age ten. She became a housekeeper and moved to Rio de Janeiro with her employers at 13 years old, where she remained until she was in her early twenties. When she returned to Acre, she resumed her friendship with Marina Silva whom she had known since childhood, and the two became involved with the Comunidades Eclesiais de Base (Ecclesiastical Base Communities), or CEBs, the Communist Party, and the Comissão Pastoral da Terra (Pastoral Commission of the Earth) or CPT, where they became passionate believers in Liberation Theology and began their work as political organizers in rubber tapper communities (Figure 1).

The work of the CEBs to raise the consciousness of rural workers contributed later to the founding in Acre of the union organization, the National Federation of Agricultural Workers (CONTAG) in 1975. CONTAG has chapters across Brazil that lobby, organize, and educate in support of rural workers' rights. Along with the support of 


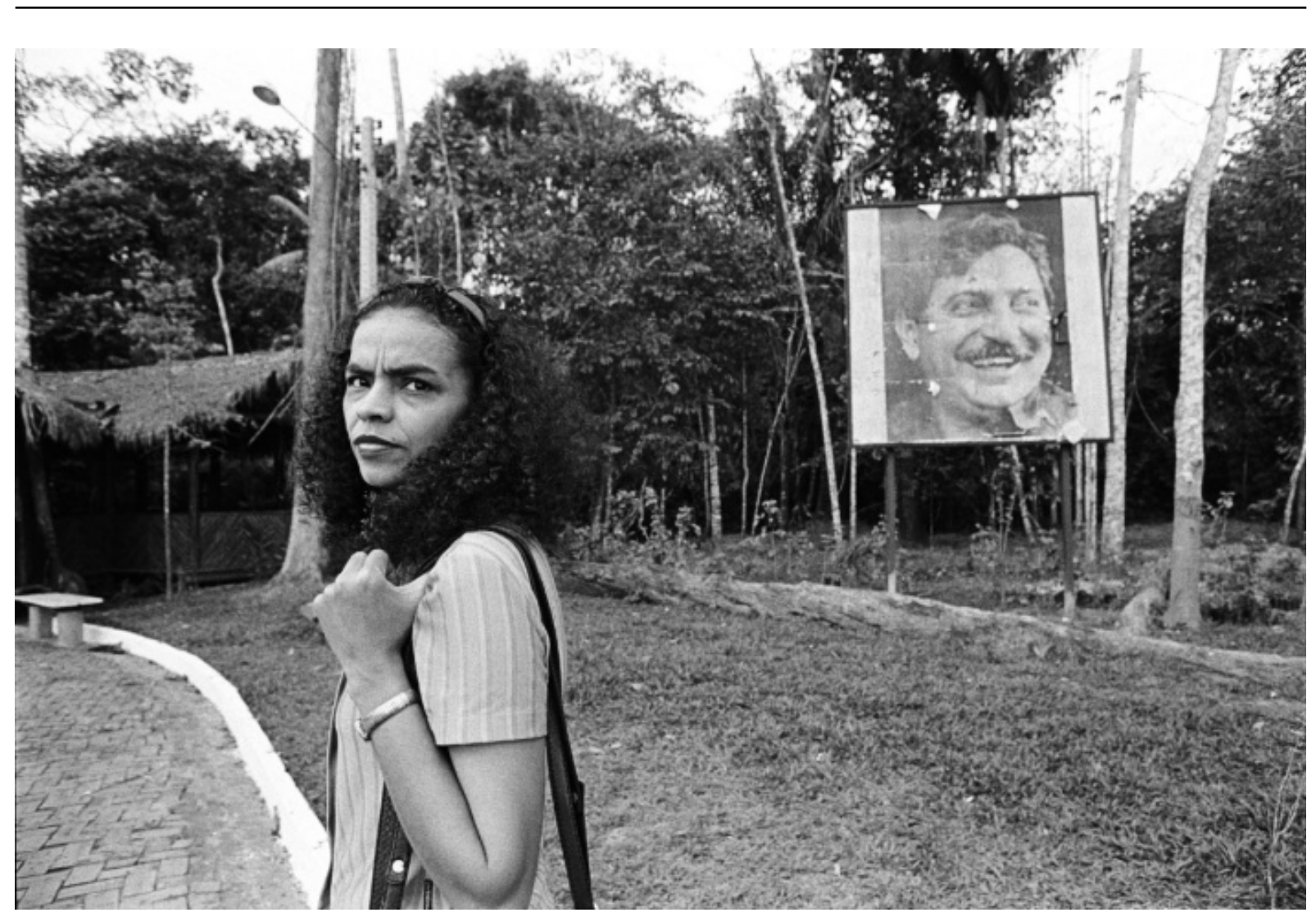

FIGURE 1 - Marina Silva (Isabella Balena).

the Ministry of Labor, CONTAG helped the rubber tappers to form a Rural Workers Union in 1977 (Allegretti, 1998). Together, Silva and Feitoza enrolled at the University of Acre as history majors. It was during these years that Silva and Feitoza met Chico Mendes, who was president of the Rural Workers' Union of Xapuri, which he had helped to found, and was involved in the formation of the Workers Party (PT) (Guerreiro, 2014). At the same time, he was engaged in the grassroots struggle against ranchers advancing into the forest of Xapuri by leading empates, in which Silva and Feitoza participated.
These three fervent activists joined forces and began to collaborate on multiple fronts.

\subsection{Ecclesiastic Base Communities (CEBs) -} an organizing force for women activists in the Amazon

Marina da Silva, Julia Feitoza, and many other women developed their political consciousness in the CEBs, which were comprised predominantly of working class, politically-oriented lay groups. "My powerful experience with the Catholic Church 
opened the pathway of my political life," says Silva (Carneiro, 2000). The government imprisoned and tortured individual clergy active in social movements but was reluctant to challenge the church as an institution, so when unions were banned, the CEBs offered political activists some cover during the oppressive years of the dictatorship. Activist clergy often facilitated these groups, and women's participation was acceptable because CEBs were associated with the church's bible-based pedagogy of Liberation Theology (Teixeira, 1988; Adriance, 1991; Drogas, 1999; Deere, 2003). The CEBs presciently recognized the untapped potential of women as catalysts for social change, and specifically encouraged their participation (Drogas, 1999).

Building on the foundational work of the CEB's and striving to unify the workers movement into national organizations, Silva, Feitoza, and Mendes co-founded the Workers Party (PT) in Acre in 1980 and the Central Única dos Trabalhadores (Workers Central) or CUT, in 1983. CUT is a central organizing force for the workers' movement in Brazil, putting political pressure on the government to enact legislation favorable to workers, such as direct elections for president, fair wages, laws defending the health and wellbeing of workers, economic policies that promote jobs and good prices for workers' products, agrarian reform, and protecting the environment and the rights of extractivist populations to forests. With founding leadership from Silva, Feitoza and others, CUT formed a National Commission for Women Workers in its early years, which has lobbied successfully for policies sensitive to the struggles of women workers.

The church-linked movement to organize workers in the spirit of Mendes spread beyond western Amazonia to the eastern Amazonian state of Pará where two religious leaders worked to educate and empower small holders. Sister Dorothy Stang was an American-born, Brazilian member of the Sisters of Notre Dame de Namur who came to Brazil from Ohio in 1966 to begin her ministry. Throughout her forty-year career, she was an ardent advocate for the rights of rural families to maintain their traditional ways of life based on extractivism and shifting cultivation in the heavily disputed forests of Pará. She collaborated with the Comissão Pastoral da Terra, an organization of the Catholic Church that fights for the rights of rural workers and defends land reforms in Brazil. She worked ceaselessly to create a sustainable development project (PDS) that would conserve the environment while allowing family farming and sustainable extractive activities in Anapu (INCRA, 2002). Sister Dorothy was named "Woman of the Year" by the state of Pará, as well as "Humanitarian of the Year" by the Brazilian Bar Association. In 2005 , tension between local farmers and ranchers and loggers became so strong that Stang met with the country's human rights officials about threats to small holders. Two weeks later, while walking along a dirt road clutching a Bible, Stang was murdered by hitmen hired by ranchers (Figure 2).

\section{Sister Lydia Constantina da Silva of the} Good Shepherd Sisters was also part of a wave of clergy that became radicalized during the years of the military dictatorship and pushed forward Mendes's vision of land and human rights in Pará state. She encouraged poor farmers to question the unequal dynamic between themselves and powerful ranchers and courageously led a group of women to occupy the union office for ten days to demand 


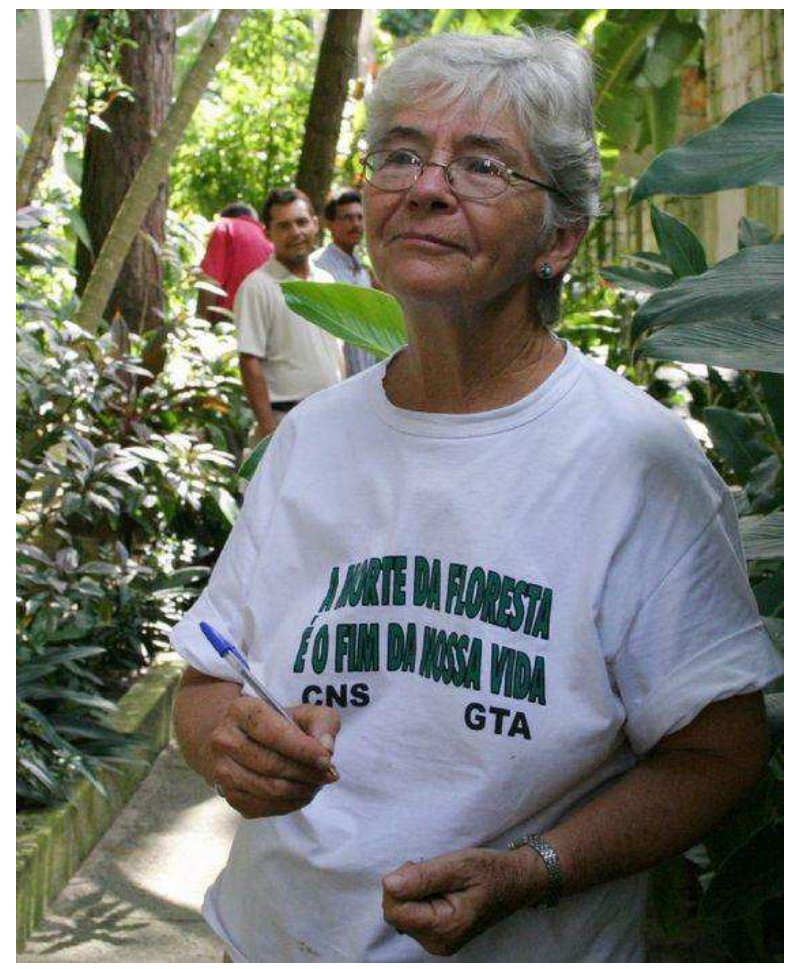

FIGURE 2 - Sr. Dorothy Stang of the Sisters of Notre Dame de Namur.

the right to vote. Surrounded by angry, gun-toting men, the women persevered and were victorious, and went on to form the Women's Association Margarida Barbosa of Nova Timboteua (Figure 3). Like Mendes' compatriots in Acre, Sister Lydia was intensely dedicated to education in the style of Paulo Freire, creating her own curriculum to teach reading to non-literate women and men using relevant aspects of their daily lives (Freire, 2000). She came to embrace the environmental movement because of the powerful link between women, land, food, and family health, encouraging women to reforest degraded areas with native fruit and medicinal species. Well-connected within Pará's women's movement, she remained a strong leader until her death in 2002 at 80 , leaving behind a cadre of empowered women, men and youth.

Due in large part to the tireless efforts of activist clergy like Silva and Stang, the workers' movement built a strong base of support throughout Amazonia during the mid-1980s. When the military dictatorship ended in 1985, it became safe to join unions and lobby openly for workers' rights, and union ranks soared. The CEBs acted as a funnel for thousands of women to social movements like the rural workers union, where many of them became leaders (Adriance, 1991; Schmink, 1981).

\subsection{Forging alliances and gaining international attention}

The practical need for rural workers to concern themselves with the environment had become evident years before the Earth Summit. Chico Mendes brought about the unification of rubber tappers with indigenous people in the Alliance of the People of the Forest in Defense of Amazonia. This solidified the connection between the rural workers unions and environmental preservation (Delgado \& Lopes, 1992). Julia Feitoza became president of the Amazonian Workers Central and received the Chico Mendes "Florestania" award by the State of Acre in 2000 in recognition of her work to stimulate the concept of florestania, or citizenship of the forest.

Marina Silva and Chico Mendes both ran unsuccessfully on the PT ticket for State Deputy in 1986. Learning from that disappointment, Silva began to pursue her political ambitions with increased determination. She was vice coordinator of CUT from 1985 to 1986. In 1988, she was elected to her 


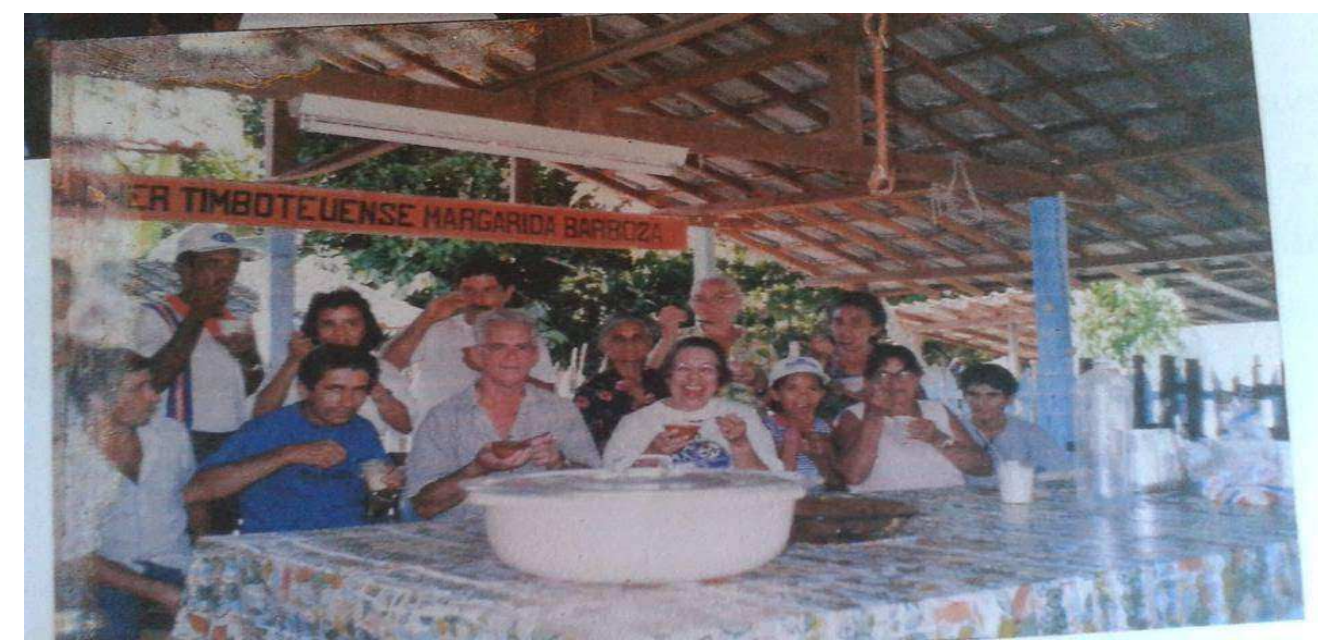

FIGURE 3 - Sr. Lygia Constantina da Silva of the Sisters of the Good Shepherd (center) (Irma Ines Evangalista).

first political office as Rio Branco Councilwoman for PT. In 1990 she was elected Federal Deputy, and in 1994 became the youngest senator to serve in Brazil's legislature, later becoming Minister of the Environment under President Lula. Respected for her integrity across the political spectrum, Silva was instrumental in helping pass Federal legislation to not only expand protected areas but also to help in instituting regulations and policies to curb rampant deforestation (Veríssimo et al., 2011).

According to data generated by Brazil's Instituto Nacional de Pesquisas Espaciais (INPE) (National Institute for Space Research), Silva's tenure as Environmental Minister began with one of the highest years of unlicensed deforestation in the Amazon region, a peak of 2.7 million ha in 2004 which decreased to 500,000 ha in 2014 (decline of $81 \%$ ).The government of Brazil achieved this significant decline in deforestation through factors including strategic implementation of federal and state policies, drops in commodity prices, credit restrictions for landowners who deforest illegally, and targeted law enforcement actions under the Plan to Prevent and Control Deforestation in the Amazon (PPCDAM) launched in 2004 (Moutinho et al., 2015). Pioneering mechanisms such as deforestation monitoring in near real-time and an innovative system of administrative embargoes based on a deforestation blacklist, have also been key in the success of this initiative (INPE, 2017, Veríssimo, 2018).

Marina Silva and Julia Feitoza were not the only women activists working alongside Chico Mendes in Acre. From 1981 until his death in 1988, Mary Allegretti worked side by side with Chico Mendes as both a compatriot and researcher who helped communicate his message to the world. In 1978, she came from the University of Brasilia to the western Amazonian state of Acre to conduct field research for her master's and later, doctoral degree, centered on conflicts between rural workers and large ranching operations. She learned that in certain regions, rubber tappers lacking formal education were trapped into debt bondage with 
the owners of the forests where they harvested latex and were unable to comprehend why they were chronically in debt. Allegretti abandoned her doctoral research and devoted herself to creating schools in the forest where rubber tappers could become literate and numerate, thereby acquiring the knowledge to liberate themselves from exploitation. In 1981, she met Chico Mendes, then a Councilman in Xapuri, and learned of the rubber tappers union and their battle with ranchers who were clear-cutting large tracks of forest where they lived and worked. Mendes viewed the rubber tappers' education as paramount to the success of the cooperative, and together Allegretti and Mendes began the Projeto Seringueiro, (Rubber Tapper Project) (Allegretti, 2008; Heyck, 2010) (Figure 4). To coordinate the Projeto Seringueiro they founded the Centro dos Trabalhadores da Amazônia (CTA) (Amazon Workers' Center) in Rio Branco, a nongovernmental organization that raised the funds for the project and which is still working with small farmers and extractivists in Acre.

The Rubber Tapper Project taught basic math and literacy skills required to run cooperatives and sell products to whomever offered the best price (Allegretti, 2008). Allegretti took the lead in orga-

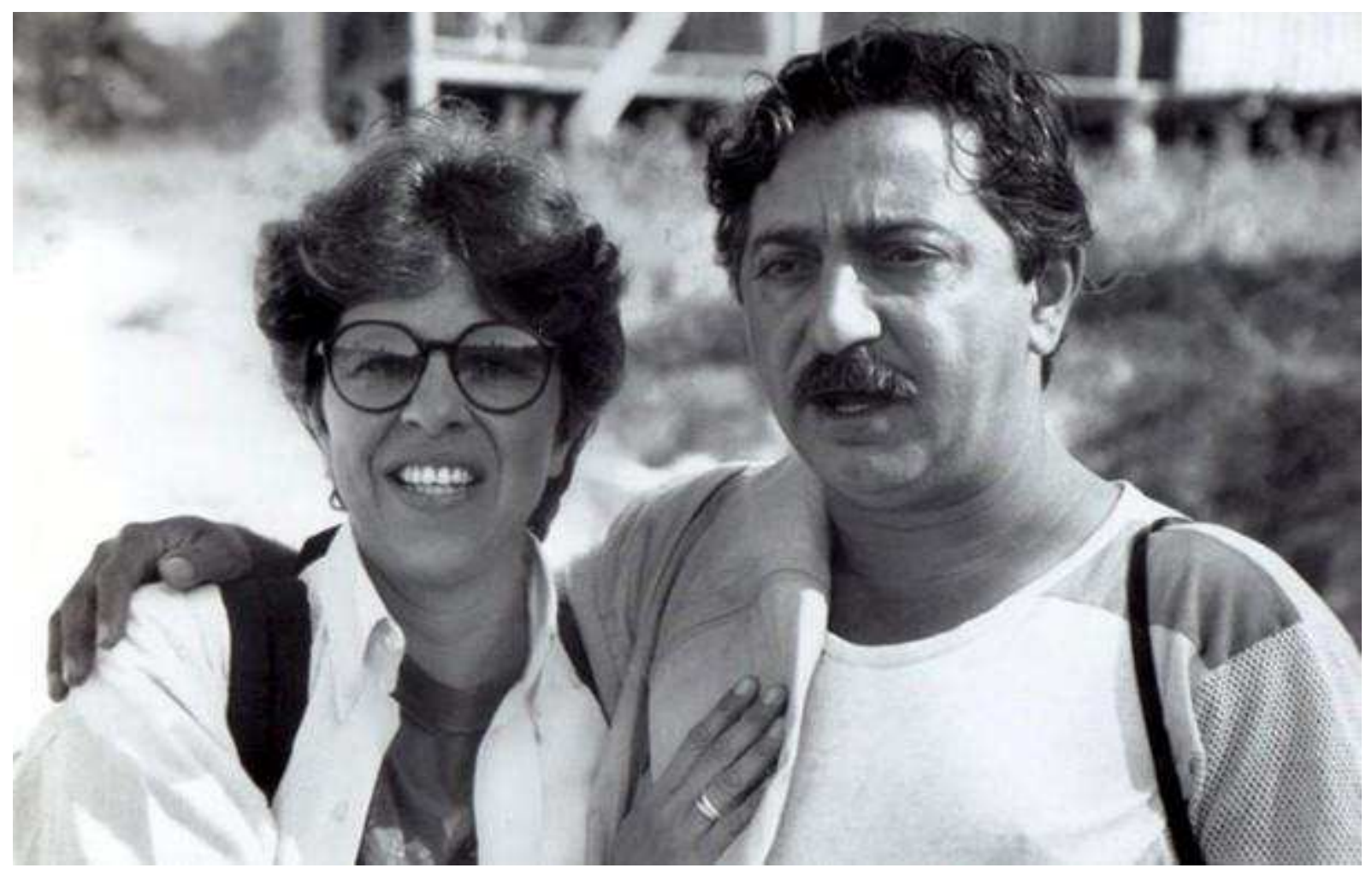

FIGURE 4 - Mary Allegretti and Chico Mendes (Miranda Smith). 
nizing adult literacy education based on the participatory pedagogy of Paulo Freire (Freire, 2000). Freire's method of instruction drew examples from the familiar landscape of the students' world and fostered political empowerment by encouraging students to reflect upon their circumstances (Giroux, 2010). Allegretti became a key figure within the rubber tappers movement, working side by side with Mendes to organize the historic first National Rubber Tappers Meeting in Brasilia in 1985 and participating in the founding of the Conselho $\mathrm{Na}$ cional de Seringueiros (CNS) (National Council of Rubber Tappers), now the Conselho Nacional de Populacoes Extrativistas (National Council of Extractivist Populations). In 1986 Allegretti organized the Institute for Amazonian Studies (IEA) in Curitiba, to support the extractive reserve concept; the IEA continues to work with the same purpose. The success spurred by these and subsequent pioneering meetings helped solidify the revolutionary concept of extractive reserves. The movement's strategy evolved from fighting not only to defend the forest, but to pursuing usufruct rights for forest dwellers and a vital rural economy based on forest goods (Rodrigues \& Rabben, 2007).

Allegretti continued to work with CNS after Mendes's assassination in 1988 to establish Brazil's first extractive reserves. The confluence of factors that permitted the success of the extractive reserve model represented a unique moment in history. Preparations for the Earth Summit in 1992 in Rio de Janeiro and Brazil's desire to renegotiate foreign debts made leaders particularly sensitive to the international outcry that ensued following Mendes' assassination, generating the political will to take significant steps to conserve large areas of Amazonia for sustainable use by extractivist populations.
Allegretti is skeptical that such an achievement would be possible now and touts it as the most significant legacy of the rubber tappers movement. "Without a doubt the biggest legacy of the rubber tappers revolution is the creation of extractive reserves, because this is permanent. It is a concept that legitimately comes from the social movement, and was a victory, not a concession. I think this is a legacy that no one could have imagined would have been possible. And if this were initiated today, it certainly would not have happened" (Belisario, 2008).

Allegretti later became involved in the negotiations for the PPG7, a pilot program for the Group of Seven wealthiest nations to protect the forests of Brazil, and in 1993 co-founded with Marina Silva, Julia Feitoza and others, the Grupo de Trabalhadores da Amazonicos (GTA) (The Amazonian Working Group), an assemblage of nongovernment organizations that accompany PPG7 projects. As Secretary of Coordination for Amazonia under President Fernando Henrique Cardoso, Allegretti was obliged to negotiate with loggers, ranchers, soy farmers, politicians, and activists, all at the same table.

\subsection{Education in support of community solidarity}

Key to the success of the Rubber Tapper Project were the teachers who devoted themselves to educating rubber tappers in remote forest communities. Dercy Telles de Carvalho was one of four original teachers who went on to become a highly respected leader in the movement. Her activism began in her late teens with liberation theology, a framework she learned in the CEBs under the gui- 
dance of Dom Moacyr, the Bishop and overall inspiration for the church in her area of Acre. When the Rural Workers' Union in Xapuri was first founded, she became a delegate, traveling to many communities for training and capacity building. Carvalho believes the role of the church was invaluable to the success of the rubber tappers movement by providing political orientation and inspiration for community building grounded in the gospel. Due in part to their geographically dispersed settlement patterns in rural areas of Amazonia, rubber tappers were highly individualistic, and it took years of work on the part of educators and organizers to cultivate a sense of community and to prioritize the wellbeing of the group. Once that notion took root, many future leaders were born (Tapera Taperá, 2018) (Figure 5).

At twenty, Carvalho became the first woman president of the Rural Workers Union in Xapuri, Acre when she was elected to complete the term of the then current president who had been forced to step down. This was a huge victory as the only

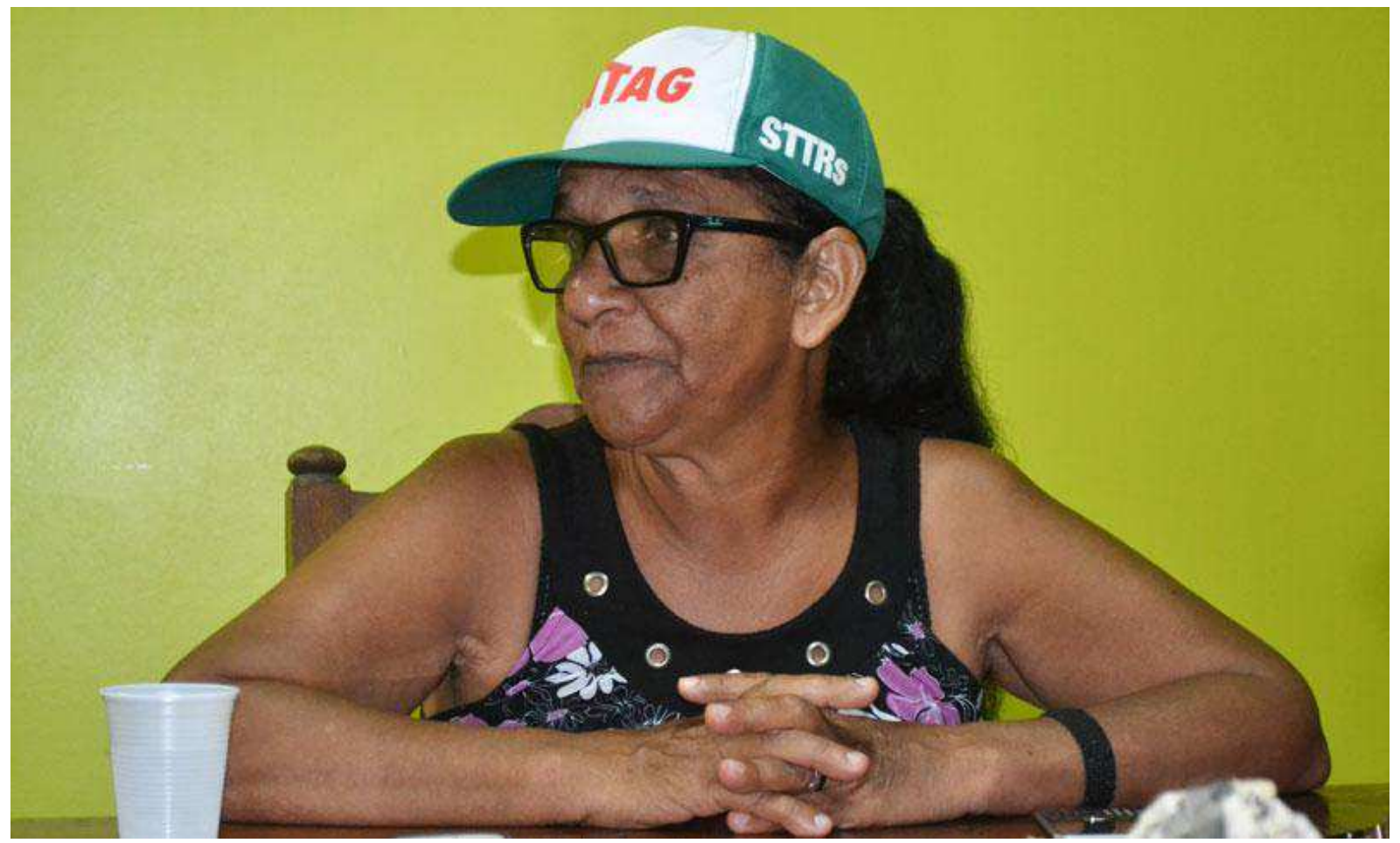

FIGURE 5 - Dercy Telles de Carvalho (CNS). 
women to participate in the unions at that time were widows. Carvalho said, "I survived two dictatorships. One was the military, the other was men... It was hard, but I broke that culture of only men being in charge of the union. At the time, in 1980, there were only two women in the union. The men didn't want to respect us because we were women. I had to pound on the table and demand their respect and attention." (Tapera Taperá, 2018). After a successful year as Union President, Carvalho returned to the countryside to continue her work as a health worker and community organizer. Meanwhile, the union fell into debt and irrelevancy as corruption took hold in the Xapuri headquarters. In 2006, she ran for Union President and was elected. Over the next seven years, first as President, then as Vice President, Carvalho worked hard to correct many of the union's shortcomings and win back membership (Tapera Taperá, 2018).

While she experienced great success in turning the union around, she saw the larger political context as moving backwards. In her mind, the Workers' Party lost its moral compass. "Its objective became staying in office, continuing in power. It ended up being just like all the others." For this reason, she no longer considers herself to be part of the mainstream social movement. "The only way to change society is to start very early with education, so we can create informed, engaged citizens who can organize and exert pressure to force politicians to respect all segments of society. This is the only way to keep change from being co-opted. When we say 'We won! The government is ours - but we can't criticize because the government is now ours' - that's the beginning of the end" (Heyck, 2010).

\subsection{Public support for women from Chico Mendes}

Sensing that Chico Mendes was gaining international fame, but that his work was largely ignored in Brazil, actress and environmental activist Lucélia Santos invited Mendes to Rio de Janeiro for a series of speaking engagements, using her influence with the media to gain him an audience. In doing so, she became inspired to co-found Brazil's Green Party, which placed environmental justice issues at the forefront of its platform (Cruz, 2000; Memórias da Floresta, 2010). At the same time, Chico Mendes realized that throughout Brazil, women were making a powerful impact on the political scene, and that it was time to embrace women's participation in the social movement. Six months before his death, he invited Lucélia Santos to come to Xapuri and give a speech at the Encontro das Mulheres dos Seringais (Women of the Rubber Trees Meeting), which united indigenous women and extractivists to discuss their struggles (Cruz, 2000).

Mendes knew that women would come from near and far to hear Santos speak, and the auditorium was filled to the rafters. After her impassioned speech calling women to action, Mendes encouraged the audience to support Marina Silva in her bid for Councilwoman of the Worker's Party in Xapuri. When Santos returned to the South she published a long article in the newspaper Folha de Sao Paulo praising Chico Mendes's work and denouncing the authorities for doing little to protect him, foretelling his assassination. She spoke at his funeral condemning the failure of democracy in Brazil, and praising Chico Mendes's work to secure a full life in harmony with the forest for extractivist populations, demanding justice for his murder, and agrarian reform. 


\subsection{Women organize in northeastern} Amazonia - Quebradeiras de Coco de Babaçu

As key women emerged to carry forward the workers' environmental movement in Acre, another powerful force was organizing women in Northeastern Amazonia. Raimunda Gomes da Silva, known as Dona Raimunda dos Cocos, who passed away at 78 in her home on November $7^{\text {th }}, 2018$, was a world-famous activist who first became radicalized by her participation with CEBs. She has spent most of her 78 years in Sete Barracas, in São Miguel do Tocantins, Bico do Papagaio, on the borders of Pará, Tocantins and Maranhão. The daughter of farmers from the Sertão in Maranhão, and mother of seven children, Dona Raimunda did not learn to read and write until she was in her twenties. In 1980, she moved with her family to Tocantins and began to question the stark division between rich and poor. She became a catechist and community organizer through the CEBs under the leadership of the priest Josimo Tavares, who arrived in 1983 to educate the local population according to the teachings of Jesus Christ. Just three years after his arrival Tavares was assassinated by powerful landowners. His tragic murder bolstered Dona Raimunda's commitment to be a lifelong activist, and she went on to become one of the founders of the Women's Agricultural Workers Union of Bico do Papagaio, and, in 1992, the beloved leader of the "Quebradeiras de Coco", or coconut breakers, women extractivists who support their families by harvesting and selling babaçu nuts.

O Movimento Interestadual de Quebradeiras de Coco Babaçu, The Interstate Movement of Babaçu Nut Breakers (MIQCB), is regarded as one of the most powerful women's union in the Americas, earning international fame and important gains. According to MIQCB estimates, there are close to 400,000 Quebradeiras de Coco in Brazil's Northeast. Dona Raimunda and the union worked to create production cooperatives that could improve workers' net gain by selling babaçu products directly to buyers. Government subsidies for select extractive products, such as rubber and babaçu, also provided economic advantages for small holders. In 1995, the Quebradeiras de Coco Babaçu assembled for the first time to address their concerns as women and as extractivists. At the time, they confronted discriminatory government policies favoring large cattle ranchers, loggers, and extensive monoculture plantations (Hecht \& Cockburn, 1989; Schmink \& Wood, 1992). The MIQCD convened the first large-scale demonstration of Amazonian women, bringing together hundreds of activists from four northern states: Pará, Piauí, Maranhão and Tocantins. The show of strength during that demonstration put the movement on the map and helped generate momentum for future gains (Figure 6).

\subsection{The National Council of Rubber Tappers creates a Women's Secretariat}

Sensing the possible loss of a powerful base through these women's secession from the National Council of Rubber Tappers, CNS diverged from its original mission to represent rubber tappers and resolved to establish a new division, The Secretariat of Women Extractivists, to address the unique needs of women extractivists as articulated by the Quebradeiras de Coco. This concession signified a profound new perspective at the interface of collective 


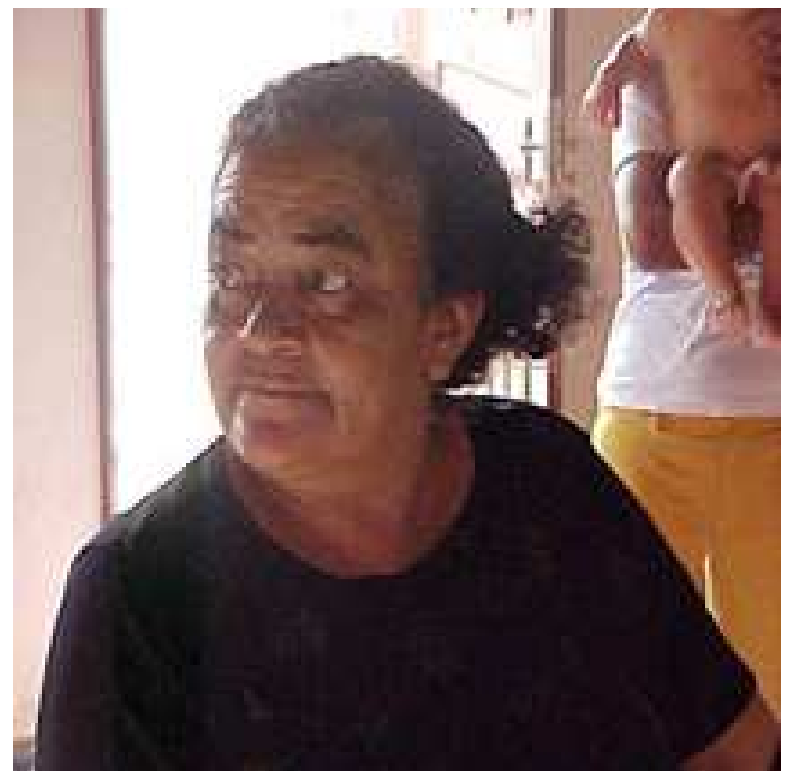

FIGURE 6 - Dona Raimunda dos Cocos (CNS).

identity and gender, foreshadowing future conflicts as well as advances encountered by female activists working with CNS. CNS's institutional embrace of Quebradeiras de Coco Babaçu also portended a later decision to rename CNS to expand representation not only to women collecting babacu, but to represent all extractivists (The National Council of Extractivist Populations).

In 1995, CNS invited Dona Raimunda to be the Secretariat's founding Director, a position she held for ten years in conjunction with her duties as a leader of the Quebradeiras de Coco. Dona Raimunda succeeded in helping hundreds of women start their own businesses, often selling value-added products using babaçu oil. She petitioned President Lula, whom she knew from his days as a union organizer, to approve a housing program building domiciles fitted for processing babaçu (Porro \& Stone, 2005). In 2008, against the resistance of ranchers, years of work by MIQCB campaigning for the "Free Babaçu Law" succeeded in 17 municipalities, guaranteeing the preservation of babaçu palms and the right for the Quebradeiras de Coco to collect nuts even on private property. Dona Raimunda received an honorary doctorate from the Federal University of Tocantins and was awarded the Guilhermina Ribeira da Silva Woman-Citizen Diploma and the Bertha Lutz Diploma by the Brazilian government. Hailed as one of Brazil's great leaders, Dona Raimunda went to to conferences in seven countries, but revealed she would prefer never to leave her native Tocantins.

\subsection{Quilombola communities struggle for land rights}

Side by side with Dona Raimunda throughout the years of organizing MIQCB was Maria Nice Machado Aires (Figure7), a pivotal leader who spans multiple movements. She is a Quilombola from Saubeiro, in the municipality of Penalva, Maranhão. Quilombolas are ethnic groups primarily composed of "rural or urban black populations who define themselves by their relationship with their land, kinship, territory, ancestry, traditions and cultural practices" (INCRA, 2018). Nice Machado began her life's work in activism at the age of 14, when she was hired by CPT to organize communities throughout her region. She became deeply involved with the rural workers' movement while a teenager, and her strong leadership qualities made her a rising star. She is leader of the Association of Quilombola Communities, and Director of the Refuge of the Forest Extractive Reserve in the municipality of Panalva, Maranhão (Memórias da Floresta, 2010). 


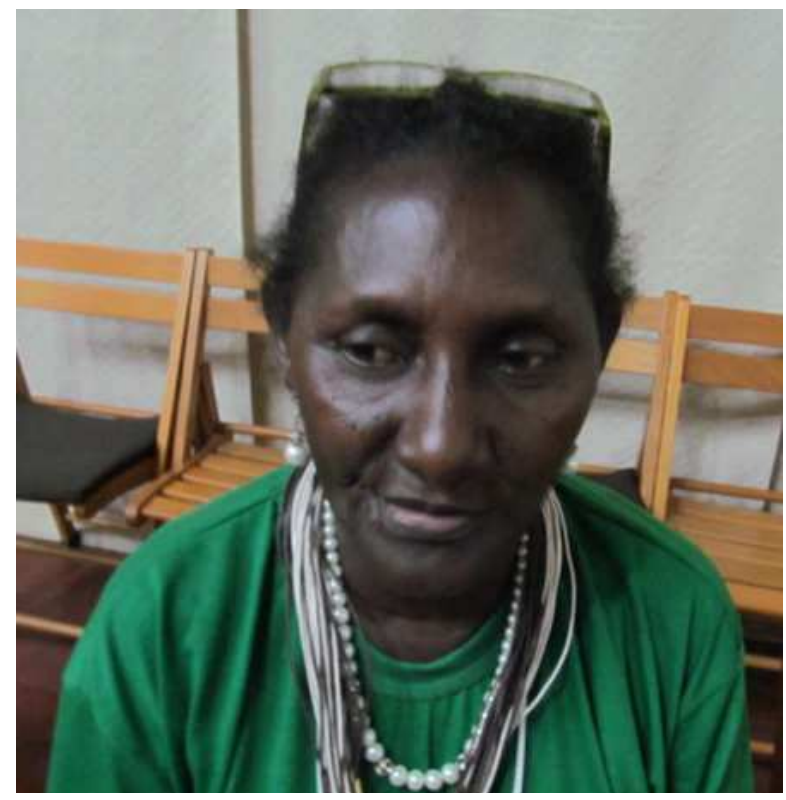

FIGURE 7 - Maria Nice Machado Aires (CNS).

Nice Machado's primary goal is to have the extractive reserve she helps to lead demarcated. Without demarcation, residents do not have the right to defend their land, which is continually under threat of encroachment by aggressive loggers and ranchers. From 2004 to 2008 Machado was Councilwoman for the Workers' Party in Penalva where she advocated for reforms and demarcation from within government. However, achieving the final step in the lengthy process towards demarcation for the extractive reserve where her Quilombo is located has been extremely difficult. In Maranhão, as in many states, powerful political clans and large landowners have obtained title to land occupied for centuries by small peasant farmers, quilombolas and their descendants (Memórias da Floresta, 2010). But Nice Machado remains undaunted. She is gratified by the many gains the movement has made in 40 years of activism and will continue working with MIQCB and local cooperatives to advance demarcation of the extractive reserve and to increase marketing and distribution of babaçu products.

\section{Systemic change}

The class and land use struggle in Brazil catalyzed by Chico Mendes has surpassed key barriers, strengthening the role of women who have subsequently achieved more presence and influence within broader social and environmental movements, such as the Movimento Sem Terra (MSD) (Landless Peasants' Movement), MIQCB, CONTAG, MAMA, GTA, CNS, Grupo da Terra (GTA), New Cartography Project of Amazonia (PNCSA), CPT, and others. Efforts to educate women and institutionalize their role within national organizations is also leading to the creation of a new generation of women leaders.

\subsection{Initiatives to educate and strengthen women}

Dona Raimunda recently passed away and other dynamic women have taken up the helm of CNS's Women's Secretariat. Since 1996, Fatima Cristina da Silva has been one of CNS's foremost leaders, traveling ceaselessly between extractive reserves in all nine Amazonian states to educate women and men about health, resource management, income generating activities, rights and citizenship, public policy, and gender issues. She was responsible for one of CNS's most renowned programs, A Bagagem das Mulheres da Floresta, the Wisdom of Forest Women, between 
2004 and 2007. With support from the Ministry of Health and the phone company Oi Futuro, the program carried out more than 300 workshops in 37 conservation units and connected several of the units via cell phone service (Portal ORM, 2007). Originally focused on women's reproductive and sexual health, the workshops grew to encompass topics including obtaining credit, human rights, community organizing, and how to manage forest and water resources. Organizers learned that women responded positively to targeted organization efforts and that programs originating from within the communities were more successful than if introduced from outside. The program received the international award Action Aid Americas 2007, the International Human Rights Award, and the National Chico Mendes award in the health and environment category.

The program was reinstated in 2017 , and Silva became responsible again for coordinating workshops on a broad array of topics in all extractive reserves (Resex), sustainable development reserves (RDS), and extractive settlement projects (PAE), in the Brazilian Amazon. In addition, she became the Director of the Chico Mendes Extractive Reserve in Acre in February 2017, a position she is particularly honored to receive as someone who was inspired by Chico Mendes when she first began her work in Acre in 1987. "Chico Mendes' assassination compelled me to take up his cause and go to Brasilia at the request of the President of CNS to work side by side with Dona Raimunda dos Cocos. She was and remains for me a great master of life and of struggle. She introduced me to many women leaders who counted Chico Mendes among their most important inspirations." (da Silva, personal communication, April 2018) (Figure 8).
The work is demanding, with insufficient funds and a near constant travel schedule requiring her to visit far flung villages in the Chico Mendes Extractive Reserve, attend meetings in Brasilia and Rio Branco, and to participate in conferences across Amazonia such as the Chamado da Floresta. Despite the challenges, she is optimistic for the future when she witnesses the next generation of leaders, many of whom were inspired to activism by programs like Bagagem das Mulheres da Floresta and the Forest School. "The legacy of Chico Mendes only serves to reinforce the great desire of women activists to continue fighting. They are warriors who motivate us to strive harder and achieve more." (Da Silva, personal communication, March 2018).

Leaders like Dona Raimunda and Cristina da Silva have made great strides towards addressing women's issues and attaining increased female participation in CNS. Thirty years ago, women were neither union members nor leaders; today, $40 \%$ of CNS leadership is female, and $25 \%$ of conservation units, which include extractive reserves, sustainable development reserves, and extractive settlement projects, have women presidents (da Silva, personal communication, March 2018).

\subsection{Rising voices, visibility and violence}

Within civil society organizations, such as CNS, the surging presence and participation of women has led to the establishment of women's secretariats and their issues have become increasingly visible. Women now participate fully in national marches such as Grito da Terra (Cry of the Earth) and attend conferences like Chamado da Floresta (Call of the Forest), engaging in policy dialogues and bringing their issues and demands to 


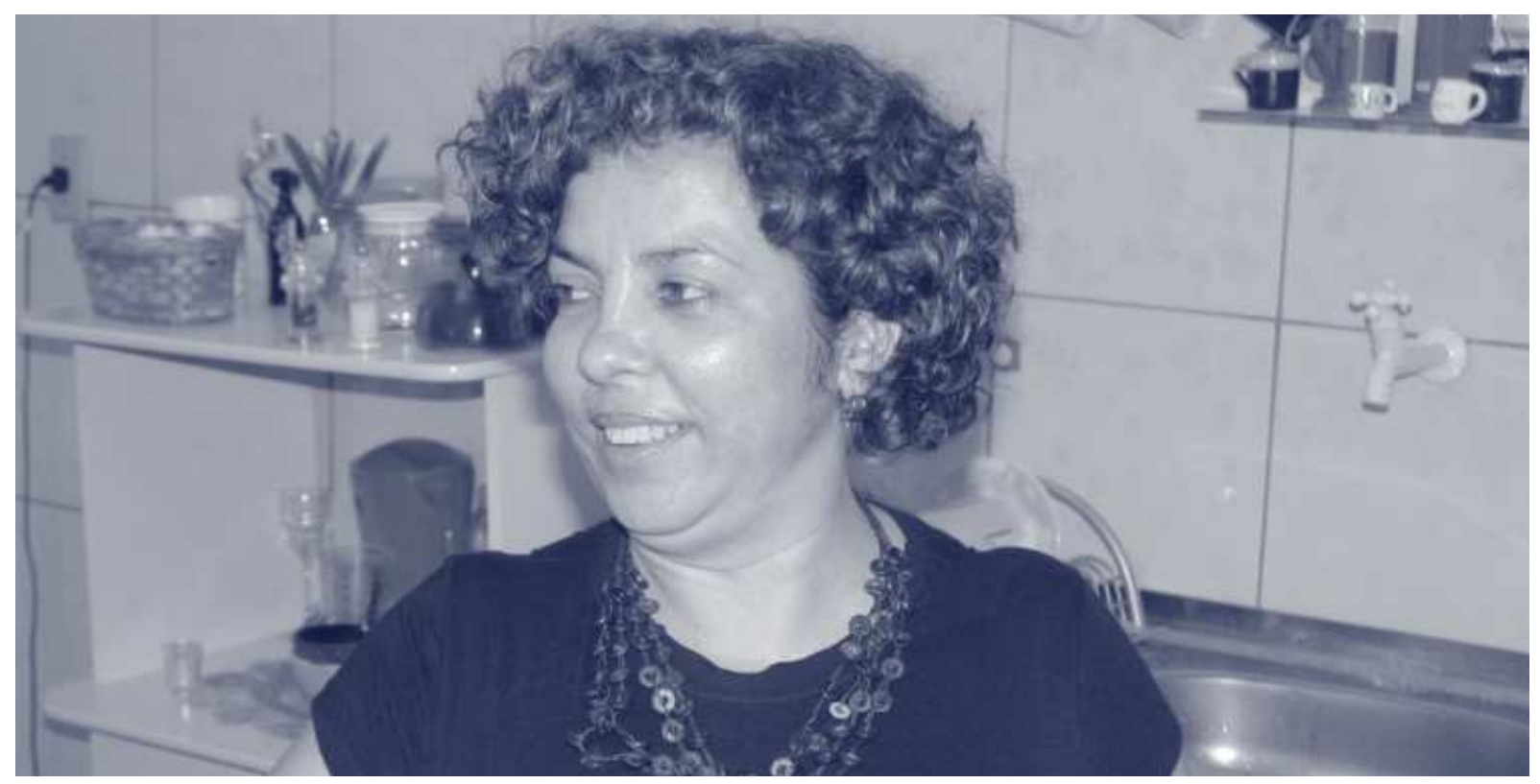

FIGURE 8 - Fatima Cristina da Silva.

legislators in Brasilia. In 2018, thousands took to the streets in Rio de Janeiro and major cities around the world to condemn the assassination of Rio de Janeiro Councilwoman Marielle Franco, and annually women take to the streets during the March of the Margaridas to recall the women who have died working for social and environmental causes, such as Maria do Espírito Santo, Katia Martins, and the indigenous Kayowá Marinalva Manoel.

As women have become more active in the political and land use arenas, violence against women has increased. In the twenty-one-year period between 1997 and 2017, records from the Comissão Pastoral da Terra (CPT) indicate that during all but four years, annually between 21 and 47 persons have been assassinated due to land use conflicts, one to four of these being women. However, in 2003 and again during 2015, 2016 and 2017, there was a sharp rise in assassinations, when $73,50,61$ and 71 people (respectively) were killed, with between five and seven of these each year being women (CPT, 2018). Of the 818 assassinations recorded over the twenty-one-year period, 7\% have been women (Figure 9). Factors which may contribute to increasing violence against women and small holders include public policies favoring large landowners, rising economic instability, and the increasing number of women openly fighting for land rights

\subsection{Educating young leaders- a key to future gains}

Chamado da Floresta (Call of the Forest) is a bi-annual conference begun in 2008 organized by CNS for extractavist populations. Hundreds of 


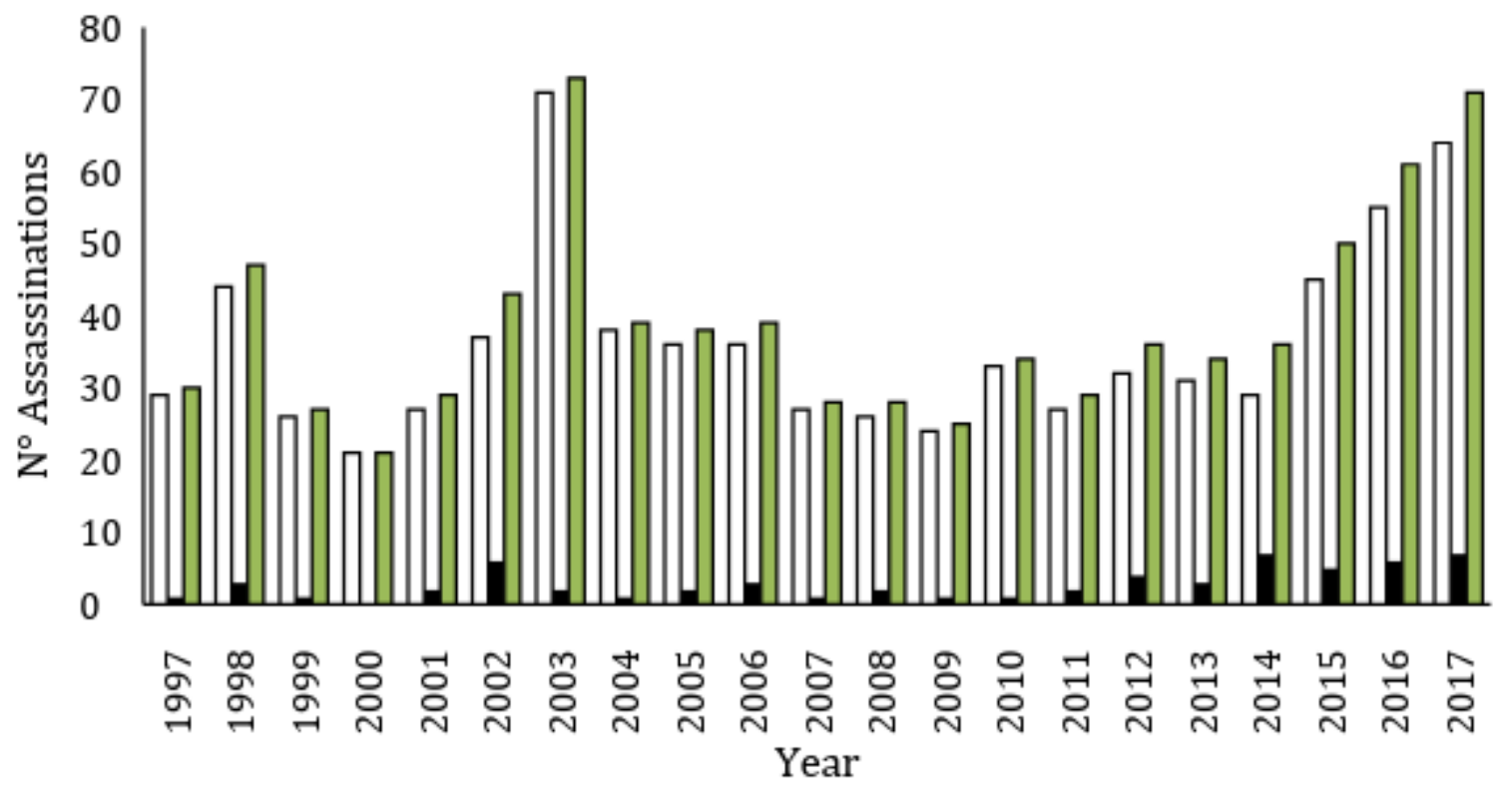

$\square$ Men

FIGURE 9 - Documented men and women assassinated in Brazil due to rural land use conflicts in Brazil 1997-2017. ${ }^{1}$

young leaders attended the most recent conference, articulating the need for a differentiated curriculum that prepares students for success within extractive reserves and that this education needs to be available in or near the reserves. Many express a strong desire to remain in their home regions but feel compelled to leave in search of education and opportunity. In recognition of this educational gap, Mary Allegretti co-founded the Forest School in Rio Branco, representing continuation of her 1980's work with the Rubber Tapper Project in Acre. The mission of the Forest School is to provide technical training to extractivist youth for careers in forestry, resource and business management, community organizing, and disciplines relevant to sustainable management of extractive reserves. Government funding for this program has recently been discontinued. Sara, a member of what may be the last graduating class of Forest School students, describes her ambitions: "My education will give me the opportunity to help extractivists to continue to protect the Amazon forest, which is the most important resource that we have. And as a technical worker it's important to continue what is our right, to preserve nature, giving new life and significance to the legacy that Chico Mendes fought so hard for, and gave his blood for, which is our Amazonia," (Torquato, 2018).

\footnotetext{
${ }^{1}$ One name during each of the following four years (1999; 2000; 2002; and 2009) may be construed as masculine or feminine. In each case, the names were designated as masculine.
} 


\subsection{A new generation of female leaders}

Edel Moraes represents the next generation of Amazonian activists from extractive reserves committed to continuing the legacy of Chico Mendes and maintaining the traditional way of life of rural, forest-reliant populations. A native of the Soure Marine Extractive Reserve on Marajó Island in Pará, Moraes began her career as a union activist. At 26 she was the youngest person to be elected as Vice President of CNS. Moraes received her bachelor's in education from the University of Pará and her master's degree in traditional communities and populations at the University of Brasilia, the first degree of its kind. Not yet 30, Moraes is intensely focused on how to give extractivists visibility and pride as a distinct population extending into the next generation. On a recent trip to a remote part of the Tapajós-Arapiuns extractive reserve, a young child fainted in front of her. Without a trace of indignation, the mother calmly explained to Moraes that it was nothing, the girl simply fainted because of hunger, as she had barely eaten for three days. Encounters like this strengthened Moraes' resolve to advocate for families living in extractive reserves. "Since the Chamado da Floresta we are trying to draw attention to these people who are unseen, and let others know that the forest has people. They are there conserving the environment, leaving the forest intact. They are citizens, children of Brazil, of Amazonia, and thanks to them, the forest that is so spoken of in Brazil and around the world, remains standing" (Teia de Saberes e Práticas, 2015). Moraes touts the Bolsa Familia program as an important step forward, as it has allowed many women to obtain identification documents and bank accounts, increasing their economic autonomy and citizenship (Ministério de Desenvolvimento Social, 2015) (Figure 10).

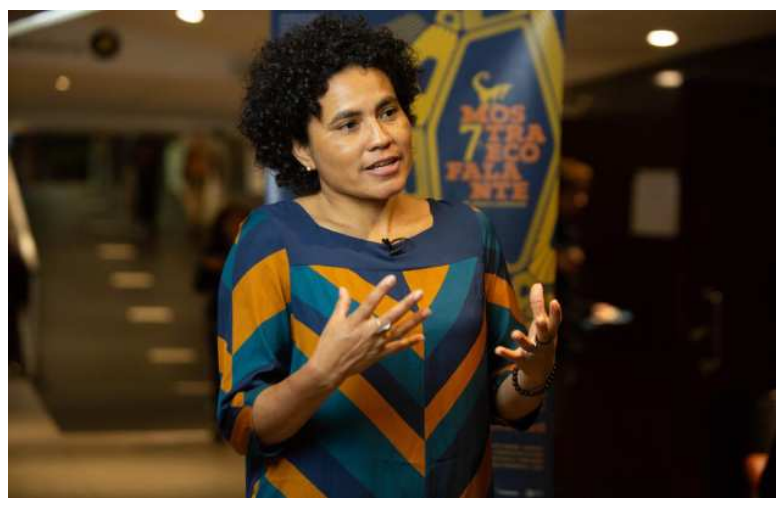

FIGURE 10 - Edel Moraes.

The future viability of extractive reserves will depend upon retaining interested youth dedicated to an extractivist way of life. One current advantage of an extractive lifestyle is that, over the last 25 years, demand for, and prices of, non-timber forest products have risen. Consumer preference for foods grown without agrotoxins and for healthy and traditional foods are on the rise. Products such as açaí and other forest fruits, fish, Brazil nut, rubber, and babaçu are selling well on the national market. There is a need to capture this trend and maximize it for long-term economic benefit. Keeping the conservation units populated, as well as fending off encroachment, are central preoccupations at this time (da Silva, personal communication, March 2018).

\section{Conclusion}

Since the death of Chico Mendes thirty years ago, Brazil instituted a system of Protected Areas covering $46 \%$ of the region (Fonseca et al., 2017). 
Furthermore, between 2004 and 2016, Brazil reduced illegal deforestation in the Amazon by $70 \%$ (INPE/PRODES, 2017). This globally significant achievement to conserve vast areas of tropical forest in the Brazilian Amazon has arisen, in part, due to political will coupled with dense scientific and technical capacity (Fonseca et al., 2017). Such an accomplishment would not have been possible however, without thousands of rural extractivist families exerting an indomitable force for change. To a considerable extent, Amazonian women have played a central role in catalyzing this conservation and human rights success.

Over the last three decades, marginalized, rural Amazonian women have persistently articulated a forceful demand for environmental and social justice. Facing oppressive forces that impeded them from gaining access to the natural resources they needed to sustain their families, humble, rural mothers and daughters became empowered. In the face of threatening loggers, ranchers, and agribusiness, repressive policies, scant material resources, personal abuse and political disenfranchisement, Amazonian women defiantly raised their voices and placed themselves in harm's way to fight for the common good. These women not only sustained Mendes' vision, they reframed it to advance women's equality, constructing vibrant advocacy networks to exert pressure on legislators and vastly improve government accountability and transparency (Montero, 2014). Considering the myriad challenges facing marginalized villagers to communicate and organize across immense distances of the Brazilian Amazon, their achievements are even more striking.

Women were not summoned to the movement. They began on the fringes as disenfranchised wives, mothers and daughters, driven by outrage over the injustices facing them daily. Some, such as Marina Silva and Mary Allegretti made their way from the margins to mainstream positions in government, national institutions, and workers' unions where they advocated for and achieved systemic changes in governmental policies to protect forests and curb deforestation. Others like Dona Raimunda dos Cocos and Dercy Telles de Carvalho remained in the forest, fighting on the frontiers for access to land, education and forest resources.

Progress has not been straightforward. In 2003, when interest in biodiversity and people's land rights was high, Marina Silva became Minister of the Environment, helping to enact legislation to expand areas of conserved Amazonian forest and to put into place safeguards to ensure their protection. In 2008, due to a growing resistance among legislators counter to what she wanted to accomplish, Silva stepped down as Minister of the Environment. However, in 2010, she ran for President on the green party ticket and again in 2014, with the Brazilian Socialist Party (PSB), garnering $21 \%$ of the vote. In 2018, as corruption engulfed the Brazilian political landscape, Silva attempted a third candidacy for Presidency, and although unsuccessful she remains a national figure that some portion of Brazilian citizens still trust. Regarding the legacy of Chico Mendes, Silva states, "we have the duty to recall the human conviviality and the Amazonian simplicity with which it all happened" (Rodrigues \& Rabben, 2007).

At the time of Mendes' death, the concept of social and environmental issues being inextricably connected was disquieting to union organizers and members of the social movement who had focused their activism principally on socioeconomic and development issues (Keck, 1995). Thirty years later, social and environmental issues are embraced 
as inherently intertwined and intrinsically linked with survival. Civil society, including rural workers unions and indigenous groups have come together and redefined the political landscape, jointly fighting for social justice and environmental protection. The movement to secure land and conserve forest rights for women and small holders in Brazil has not abated but evolved through intergenerational exchange and shared bonds born of struggle, with enduring resonance worldwide.

\section{Acknowledgements}

We would like to thank Mary Allegretti for her recollections, Isabella Balena for use of her photo of Marina Silva, and the courageous women working to conserve forests in Brazil and beyond.

\section{References}

Adriance, M. Agents of change: the roles of priests, sisters, and lay workers in the grassroots Catholic Church in Brazil. Journal for the Scientific Study of Religion, 30(3), 292-305, 1991.

Alexander, M. J. Pedagogies of crossing: meditations on feminism, sexual politics, memory, and the sacred. Duke University Press, 2006.

Anderson, A. Land-use strategies for successful extractive economies in Amazonia, Advances in Economic Botany, 9, 67-77, 1992.

Allegretti, M. H. Chico Mendes ten years before. In: Schwartzman, S. (Ed.). From the ashes: reflections on Chico Mendes and the future of the rainforest. Washington DC: Environmental Defense Fund, 1998.

Allegretti, M. H. A construção social de políticas públicas: Chico Mendes e o movimento dos seringueiros. Desenvol- vimento e Meio Ambiente, 18, 39-59, 2008.

Araujo, J. da S.; Araujo, A. T. de. Levantamento socio-economico sobre a populacão seringueirajunto ao Rio Aripuarin, Estado do Amazonas. Manaus, 1987.

Belisario, A. Revista de história da Biblioteca Nacional, 2008. Available in: http://maryallegretti.blogspot.com/. Accessed April, 2018.

Brown, K.; Rosendo, S. The institutional architecture of extractive reserves in Rondonia, Brazil, The Geographical Journal, 166(1), 35-48, 2000.

Campbell, C. Out on the front lines but still struggling for voice: women in the rubber tappers' defense of the forest in Xapuri. The Ecologist, 27(2), 46-54, 1997.

Carneiro, C. A senadora abraça a palavra de Deus: Marina Silva, do PT, supera doença causada por contaminação de mercúrio e deixa a militância na Igreja Católica para abraçar a religião evangélica. Istoé. 2000. Available in: https://www. terra.com.br/istoegente/54/reportagem/rep_senadora.htm) 2000. Accessed April 2018

CPT - Comissão Pastoral da Terra: Centro de Documentação Dom Tomás Balduino. Categoria Assassinatos: arquivos 1987-2017. https://www.cptnacional.org.br/component/ jdownloads/category $/ 5$-assassinatos? Itemid $=-1>$ Accessed July 2018.

Cruz, T. A. Movimento de mulheres camponesas do Acre: 25 anos de organização e lutas, 2000. http://www.encontro2014.historiaoral.org.br/resources/anais/8/1398902318_ARQUIVO_Textocompleto.25anosdeMMCAC.pdf Accessed November 2018.

Deere, C. D. Women's land rights and rural social movements in the Brazilian agrarian reform. Journal of Agrarian Change, 3(1/2), 257-288, 2003.

Delgado, M. B.; Lopes, M. M. Mulheres trabalhadoras e meio ambiente: um olhar feminista no sindicalismo. Revista Estudos Feministas, 155-162, 1992.

Drogas, C. A. No land of milk and honey: women CEB activists in post transition Brazil. Journal of Inter-American Studies and World Affairs, 41(4), 31-55,1999. 
Edwards, E. Charisma and the fiction of black leadership. University of Minnesota Press, 2012.

Flor, A. Marina Silva: a filha da floresta. Folha de S.Paulo. June 2, 2010. Available in: http://www1.folha.uol.com.br/ poder/2010/06/744238-marina-silva-a-filha-da-floresta. shtml Accessed April 2018.

Fonseca, A.; Salomão, R.; Ribeiro, J.; Souza Jr., C. Ameaça e pressão de desmatamento em Áreas Protegidas: SAD de agosto a outubro de 2017. Belém: Imazon, 2017.

Freire, P. Pedagogy of the oppressed. New York, Continuum, 2000.

Giroux, H. A. Rethinking education as the practice of freedom: Paulo Freire and the promise of critical pedagogy. Policy Futures in Education, 8(6), 2010.

Guerreiro, M. A saga da companheira Sara: dos seringais ao PT. Ratio Pro Libertas. September 11, 2014. Available in: http://www.rplib.com.br/index.php/artigos/item/4239-a-saga-da-companheira-sara-dos-seringais-ao-pt. Accessed April 2018.

Hecht, S. Factories, forests, fields, and families: gender and neoliberalism in extractive reserves. Journal of Agrarian Change, 7(3), 2007.

Hecht, S.; Cockburn, A. The fate of the forest: developers, destroyers and defenders of the Amazon. London and New York: Verso, 1989.

Heyck, D. L. D. Schools in the forest: how grassroots education brought political empowerment to the Brazilian Amazon. Sterling: Kumarian Press, 2010.

Hemming, J. Amazonian frontier. Cambridge University Press, 1987.

INCRA. Portaria Incra, no. 1.040, 11 de Dezembro 2002. Accessed July 52018.

INCRA. National Institute of Colonization and Agrarian Reform. Legislação Quilombola Condensada. http://www. incra.gov.br/estrutura-fundiaria/quilombolas. Accessed $7 / 5 / 2018$.

INPE/PRODES. Monitoramento da floresta Amaznica brasileira por satlite projeto PRODES. São Paulo, Brasil: Instituto
Nacional de Pesquisas Espaciais (INPE) 2017. http://www. obt.inpe.br/prodes. Accessed May 12018

Jenkins, J. Resource mobilization theory and the study of social movements. Annual Review of Sociology, 9, 527$553,1983$.

Keck, M. Social equity and environmental politics in Brazil: lessons from the rubber tappers in Acre. Comparative Politics, 27(4), 409-424, 1995.

Memórias da floresta: movimentos socioambientais do Acre. Rio Branco: Biblioteca da Floresta, 2010.

Mendes, C. A Luta dos povos da floresta. Palestra realizada em de junho de 1988, promovida pelo Departamento de Geografia da USP e AGB-SP, 1988.

Ministério de Desenvolvimento Social. Edel Moraes- vice presidente do CNS. 10/19/2015. Available in: https://www. youtube.com $/$ watch? $\mathrm{v}=\mathrm{vtg}-\mathrm{SJQu}$ LYY\&feature=youtu. be\&app=desktop Accessed April 2018.

Montero, A. Brazil: reversal of fortune. Hoboken: John Wiley \& Sons, 2014.

Moutinho, P.; Guerra, R.; Azevedo-Ramos, C. Achieving zero deforestation in the Brazilian Amazon: What is missing. Elementa: Science of the Anthropocene, 4, 125, 2015. doi: 10.12952/journal.elementa.000125

Pfaff, A.; Robalino, J.; Herrera, D.; Sandoval, C. Protected Areas Impacts on Brazilian Amazon Deforestation: Examining Conservation - Development Interactions to Inform Planning. PLoS ONE, 10(7), e0129460, 2015. doi: 10.1371/ journal.pone. 0129460

Polletta, F.; Jasper, J. Collective identity and social movements. Annual Review of Sociology, 27, 283-305, 2001.

Porro, N. M.; Stone, S. Diversity in living gender. In: Colfer, C. J. P. (Ed.). The equitable forest. Diversity, community, and resource management. Washington DC: RFF Press, 2005.

Portal ORM. Fátima Cristina: a vez dos povos da floresta. August 24, 2007. Available in:http://noticias.orm.com.br/ noticia.asp?id $=281512 \& \% 7 \mathrm{Cf} \% \mathrm{C} 3 \%$ A 1 tima + cristina $+\mathrm{a}+-$ vez + dos + povos + da + floresta\#.WswL2NPwadE. Accessed April 2018. 
Rodrigues, G.; Rabben, L. Walking the forest with Chico Mendes: struggle for justice in the Amazon. Austin: University of Texas Press, 2007.

Saldaña-Portillo, M. J. The revolutionary imagination in the Americas and the age of development. Duke University Press, 2003.

Schmink, M. Women in abertura politics. Signs, 7(1), 115-134, 1981.

Schmink, M.; Wood, C. Contested frontiers in Amazonia. Columbia University Press, 1992.

Schwartzman, S.; Alencar, A.; Zarin, H.; Santos Souza, A. P. Social movements and large scale tropical forest protection on the Amazon frontier: conservation from chaos. Journal of Environment and Development, 19(3), 274-299, 2010.

Shanley, P.; Da Silva, F. C.; MacDonald, T. Brazil's social movements, women, and forests: a case study from the National Council of Rubber Tappers. International Forestry Review, 13(2), 233-244, 2011.

Simonian, L. T. Mulheres seringueiras na Amazônia Brasileira: uma vida de trabalho silenciado. In: Alvares, M. N.; D'incao, M. (Eds.). A mulher existe? Uma contribuição ao mulher e gênero na Amazônia. Belem: Brazil. Museum Paraense Emilio Goeldi, 97-115, 1995.

Tapera Taperá, Debate: 30 anos sem Chico Mendes, a Amazonia e a reforma agraria. In Facebook, March 7, 2018. Available in: https://www.facebook.com/taperataperah/ videos/852889244902058/. Accessed April 2018.

Teia de Saberes e Práticas. Moraes: Conselho Nacional das Populações Extrativistas. On Youtube, April 5, 2015. Available in: https://www.youtube.com/watch?v=wcE86b57Rc8\&feature=youtu.be Accessed April 2018.

Teixeira, F. Comunidades eclesiais de base: bases teológicas. Petrópolis: Vozes, 1988.

Torquato, D. O legado de Chico Mendes para os jovens extrativistas \#RUMO ao IV Chamado da Floresta. On Youtube, March 5, 2018. Available in: https://www.youtube. $\mathrm{com} /$ watch? $\mathrm{v}=\mathrm{SJivUxP}$ 76Jg\&feature $=$ youtu.be Accessed April 2018.

Verissimo, A.; Rola, A.; Vedoveto, M.; de Melo Futado, S.
Protected areas in the Brazilian Amazon: challenges and opportunities. Belém: IMAZON/ISA, 2011.

Verissimo, A. How to address deforestation: lessons from the Brazilian Amazon. Presentation, Princeton University, March 24, 2018. 